\title{
Meer licht op de regionale arbeidsmarkt
}

Citation for published version (APA):

de Grip, A. (1991). Meer licht op de regionale arbeidsmarkt. Researchcentrum voor Onderwijs en Arbeidsmarkt, Faculteit der Economische Wetenschappen. ROA Reports No. 4 https://doi.org/10.26481/umarep.1991004

Document status and date:

Published: 01/01/1991

DOI:

10.26481/umarep.1991004

Document Version:

Publisher's PDF, also known as Version of record

\section{Please check the document version of this publication:}

- A submitted manuscript is the version of the article upon submission and before peer-review. There can be important differences between the submitted version and the official published version of record.

People interested in the research are advised to contact the author for the final version of the publication, or visit the DOI to the publisher's website.

- The final author version and the galley proof are versions of the publication after peer review.

- The final published version features the final layout of the paper including the volume, issue and page numbers.

Link to publication

\footnotetext{
General rights rights.

- You may freely distribute the URL identifying the publication in the public portal. please follow below link for the End User Agreement:

www.umlib.nl/taverne-license

Take down policy

If you believe that this document breaches copyright please contact us at:

repository@maastrichtuniversity.nl

providing details and we will investigate your claim.
}

Copyright and moral rights for the publications made accessible in the public portal are retained by the authors and/or other copyright owners and it is a condition of accessing publications that users recognise and abide by the legal requirements associated with these

- Users may download and print one copy of any publication from the public portal for the purpose of private study or research.

- You may not further distribute the material or use it for any profit-making activity or commercial gain

If the publication is distributed under the terms of Article $25 \mathrm{fa}$ of the Dutch Copyright Act, indicated by the "Taverne" license above, 


\title{
MEER LICHT OP DE REGIONALE ARBEIDSMARKT
}

\author{
ROA-R-1991/4
}

\begin{abstract}
-Discussienota ten behoeve van de expertmeeting 'Regionale arbeidsmarktinformatie' van het Landelijk Dienstverlenend Centrum

op 10 april 1991 .
\end{abstract}

A. de Grip

RESEARCHCENTRUM VOOR ONDERWIJS EN ARBEIDSMARKT

Faculteit der Economische Wetenschappen

Rijksuniversiteit Limburg

Maastricht, april 1991 


\section{MEER LICHT OP DE REGIONALE ARBEIDSMARKT}

ROA-R-1991/4

-Discussienota ten behoeve van de expert-
meeting 'Regionale arbeidsmarktinformatie'
van het Landelijk Dienstverlenend Centrum

van het Landelijk Dienstverlen
op 10 april 1991-

A. de Grip

RESEARCHCENTRUM VOOR ONDERWIJS EN ARBEIDSMARKT

Faculteit der Economische Wetenschappen

Rijksuniversiteit Limburg

Maastricht, april 1991 


\section{CIP-GEGEVENS KONINKLIJKE BIBLIOTHEEK, DEN HAAG}

Grip, A. de

Meer licht op de regionale arbeidsmarkt: discussienota ten behoeve van de expertmeeting 'Regionale arbeidsmarktinformatie' van het Landelijk Dienstverlenend Centrum op 10 april 1991 / A. de Grip. - Maastricht: Researchcentrum voor Onderwijs en Arbeidsmarkt, Faculteit der Economische Wetenschappen, Rijksuniversiteit Limburg. - (Rapport / Researchcentrum voor Onderwijs en Arbeidsmarkt, ISSN 0922-8098; 1991/4)

Met lit. opg.

ISBN 90-5321-056-3

Trefw.: arbeidsmarkt. 
INHOUDSOPGAVE

bladzijde

VOORWOORD

1. INLEIDING

2. GEBRUIKERSBEHOEFTEN 3

3. BESCHIKBARE GEGEVENS OP REGIONAAL NIVEAU 9

4. ENKELE RECENTE INITIATIEVEN 17

$\begin{array}{ll}\text { 4.1. Een negental initiatieven } & 17\end{array}$

4.2. Betekenis voor het informatiesysteem I-See! 24

$\begin{array}{lr}\text { 5. BESLUIT } & 27\end{array}$

$\begin{array}{ll}\text { LITERATUUR } & 31\end{array}$ 


\section{VOORWOORD}

Deze inventariserende studie is uitgevoerd in opdracht van het Landelijk Dienstverlenend Centrum voor Studie- en Beroepskeuzevoorlichting (LDC) ten behoeve van de expert-meeting 'Regionale arbeidsmarktinformatie', gehouden op 10 april 1991 te Utrecht.

Het rapport is geschreven met een tweeledig doel. Enerzijds is het bedoeld om het LDC te informeren over de behoefte aan en de beschikbaarheid van regionale arbeidsmarktinformatie. Anderzijds heeft het als raamwerk gediend voor de discussie op de bovengenoemde expertmeeting. Daarbij moet uitdrukkelijk worden opgemerkt dat de in het rapport beschreven recente initiatieven tot een verbeterde beschikbaarheid van regionale arbeidsmarktinformatie in dit rapport zijn beoordeeld vanuit hun toepasbaarheid voor een, regionaal gespecificeerd, landelijk informatiesysteem over de volle breedte van de arbeidsmarkt.

De studie is uitgevoerd door dr. A. de Grip, als hoofdonderzoeker verbonden aan het Researchcentrum voor Onderwijs en Arbeidsmarkt (ROA). Drs. H. Berendsen assisteerde bij het inventariseren van het beschikbare datamateriaal. Met dank aan prof. dr. J.A.M. Heijke (directeur ROA) en drs G.R. de Wit (hoofd arbeidsmarkt LDC) voor hun commentaar op een eerste versie van het rapport en de participanten van de expert-meeting, wiens opmerkingen er toe hebben geleid dat het aldaar gepresenteerde concept-rapport op enkele punten kon worden bijgesteld. 


\section{INLEIDING}

Door het besef dat de gebrekkige aansluiting tussen vraag en aanbod op de arbeidsmarkt vaak een regio-specifiek karakter heeft, is de laatste jaren de beschikbaarheid van regionale arbeidsmarktinformatie steeds meer in de belangstelling komen te staan. Dit besef heeft het afgelopen decennium ook geleid tot een verschuiving in de richting van een toenemende decentralisatie van het arbeidsvoorzieningsbeleid van de overheid. Met de creatie van de getripartiseerde bestuursstructuur voor het arbeidsvoorzieningsbeleid heeft deze decentralisatietendens opnieuw een belangrijke impuls gekregen, doordat in de nieuwe bestuursstructuur de beleidsplanning in belangrijke mate op regionaal niveau is komen te liggen. Van de in totaal 28 Regionale Besturen voor de Arbeidsvoorziening (RBA's) wordt verwacht dat zij een op de specifieke situatie afgestemde invulling kunnen geven aan een alom gewenst activerend arbeidsmarktbeleid.

Naast het arbeidsvoorzieningsbeleid is de beschikbaarheid van regionale arbeidsmarktinformatie ook van groot belang voor de studie- en beroepskeuzevoorlichting in het algemeen, de onderwijsplanning van het reguliere onderwijs en het personeelswervings- en -planningsbeleid van zowel het bedrijfsleven als non-profit organisaties. Het gaat hierbij zowel om informatie over de actuele arbeidsmarktsituatie, als om informatie over de verwachte toekomstige aansluitingsproblemen tussen vraag en aanbod op de arbeidsmarkt. Globaal gesproken vormen bovenstaande vier gebruiksdoelen van regionale arbeidsmarktinformatie de directe gebruiksdoelen van de informatie. Daarnaast kan de regionale arbeidsmarktinformatie op indirecte wijze voorzien in gebruikersbehoeften uit hoofde van het verkeers- en vervoersbeleid, het woningbouwbeleid en het regionale beleid in het algemeen.

Dit rapport heeft als doel een beeld te schetsen van de huidige stand van zaken ten aanzien van de beschikbaarheid van regionale arbeidsmarktinformatie in relatie tot de gebruikerswensen. Het rapport is samengesteld mede met het oog op de verschillende initiatieven die momenteel worden ondernomen om te komen tot een verbetering van de informatievoorziening op dit terrein. Wat het laatste betreft kan dit rapport worden gezien als een discussienota op basis waarvan kan worden nagegaan in hoeverre deze initiatieven op elkaar zouden kunnen worden afgestemd.

Eerst zal in het volgende hoofdstuk worden ingegaan op de diverse gebruikersbehoeften ten aanzien van regionale arbeidsmarktinformatie. Daarbij staan de bovengenoemde directe gebruikersbehoeften centraal, in het bijzonder de studie- en beroepskeuzevoorlichting en het bemiddelings- en scholingsbeleid in het kader van de arbeidsvoorziening. Daarna zal in 
$-2-$

hoofdstuk 3 een globale beschrijving worden gegeven van de beschikbare regionale arbeidsmarktinformatie. Daarbij zal met name aandacht worden besteed aan de mogelijkheden om de informatie te verbijzonderen naar bedrijfs-, beroeps- en opleidingscategorieën. In hoofdstuk 4 wordt vervolgens ingegaan op enkele recent genomen initiatieven om te komen tot een verbetering van de beschikbaarheid van regionale arbeidsmarktinformatie. Ook zal daarbij worden ingegaan op de mogelijke betekenis van deze initiatieven voor het informatiesysteem ISee! van het Landelijk Dienstverlenend Centrum (LDC). Tenslotte worden in hoofdstuk 5 enkele concluderende opmerkingen gemaakt. 


\section{GEBRUIKERSBEHOEFTEN}

In het voorgaande hoofdstuk werden de diverse mogelijke gebruiksdoelen van regionale arbeidsmarktinformatie summier aangeduid. Enerzijds werd daarbij een viertal directe gebruiksdoelen genoemd:

- het arbeidsvoorzieningsbeleid;

- de studie- en beroepskeuzevoorlichting;

- de onderwijs- en curriculumplanning;

- het wervings- en personeels(plannings)beleid van arbeidsorganisaties.

Voor deze gebruiksdoelen is het traceren van arbeidsmarktdiscrepanties doel op zich. Anderzijds kan regionale arbeidsmarktinformatie op indirecte wijze van nut zijn voor diverse andere gebruiksdoelen, zoals het verkeers- en vervoersbeleid, het woningbouwbeleid en het regionale (economische) beleid in het algemeen.

De laatstgenoemde gebruiksdoelen onderscheiden zich van de directe gebruiksdoelen, met name door de geringere noodzaak naar bedrijf, beroep of opleiding te differentieren. Doorgaans is een globale opsplitsing naar bijvoorbeeld bedrijfssector of opleidingsniveau voor de indirecte gebruiksdoelen reeds toereikend. Deze informatie dient met name voor het verklaren van interregionale mobiliteits- en pendelstromen. Ten aanzien van de genoemde directe gebruiksdoelen is een tamelijk vergaande differentiatie naar bedrijf, beroep en opleiding daarentegen vaak een vereiste, omdat de aansluitingsproblemen tussen vraag en aanbod pas op een lager aggregatieniveau op adequate wijze in beeld kunnen worden gebracht.

Om een indruk te geven van de aard van deze informatiebehoefte zal eerst nader worden ingegaan op een tweetal van de bovengenoemde directe gebruiksdoelen, te weten de studie- en beroepskeuzevoorlichting en het arbeidsvoorzieningsbeleid. Daarbij wordt binnen het arbeidsvoorzieningsbeleid weer een verder onderscheid gemaakt tussen het bemiddelingsbeleid en het scholingsbeleid. Op meer schematische wijze zal daarna worden ingegaan op de beide andere directe gebruiksdoelen, de onderwijsplanning en het wervings- en personeelsbeleid van arbeidsorganisaties.

Het informatiesysteem voor beroeps- en opleidingskeuze 'I-See!' van het LDC geeft een goede indruk van de aard van de informatiebehoefte vanuit de studie- en beroepskeuzevoorlichting. Vertrekpunt bij de bepaling van de invulling van de arbeidsmarktinformatie in I-See! was een wensenlijst van Pere (1986) ten aanzien van de informatie die in zijn ogen idealiter beschikbaar zou moeten zijn voor de studie- en beroepskeuzevoorlichting: 
1. De ontwikkeling van de omvang van het beroepsdomein.

2. Het aandeel van het aantal werkenden binnen het domein in de totale beroepsbevolking.

3. Het aandeel van verschillende categorieën beroepsbeoefenaren in het desbetreffende domein.

4. Het opleidingsniveau en de opleidingsrichting van beroepsbeoefenaren die in een bepaald domein werkzaam zijn.

5. De mate van crisisgevoeligheid van het beroepsdomein.

6. De leeftijdsopbouw van de beroepsbeoefenaars.

7. De te verwachten ontwikkeling van het domein.

8. De te verwachten toestroom van arbeidskrachten naar het domein.

9. De te verwachten discrepantie tussen vraag en aanbod in het beroepsdomein.

10. Mogelijke regionale verschillen in werkgelegenheid.

In het huidige I-See! produkt wordt op de eerstgenoemde 9 punten landelijke informatie verstrekt. Bovendien wordt soortgelijke informatie verschaft voor de onderscheiden opleidingstypen. Daarbij vindt de confrontatie van vraag en aanbod niet plaats naar beroepsdomein, maar naar opleidingstype. Tevens wordt een beeld geschetst van de actuele arbeidsmarktsituatie naar opleidingstype.

Globaal gesproken worden er voor zowel opleidingen als beroepen drie soorten informatie verstrekt:

- actuele data en trends;

- arbeidsmarktindicatoren;

- middellange termijnprognoses.

De keuze van deze prognosetermijn is ingegeven door de behoefte om degenen die op een bepaald moment voor een opleidingskeuze staan informatie te geven over de verwachte situatie op de arbeidsmarkt op het moment dat men, na het afronden van de opleiding, voor het eerst op zoek gaat naar een geschikte baan. De arbeidsmarktindicatoren kunnen worden gezien als 'risico-indicatoren' van een bepaalde opleidings- of beroepskeuze. Daarbij wordt enerzijds een indicatie gegeven van de conjunctuurgevoeligheid van de werkgelegenheid in een beroepsdomein en anderzijds een beeld geschetst van de uitwijkmogelijkheden naar andere beroepsdomeinen en/of bedrijfssectoren. Het laatste geeft een indruk van de arbeidsmarktflexibiliteit van de schoolverlaters c.q. beroepsbeoefenaren.

In principe kan worden gesteld dat op veel punten waarover op dit moment landelijke informatie wordt verstrekt, behoefte bestaat aan regionale data. Mogelijk vormt de indicator van de conjunctuurgevoeligheid van de werkgelegenheid hierbij een uitzondering. Ook kan een 
uitzondering worden gemaakt voor de opleidingen binnen het Wetenschappelijk Onderwijs en mogelijk ook het Hoger Beroepsonderwijs, waarvan de arbeidsmarkt in de praktijk slechts in geringe mate in regionale segmenten kan worden opgedeeld. Wel zal er ook op regionaal niveau behoefte bestaan aan het toetsen van de effectiviteit van het studie- en beroepskeuzevoorlichtingsbeleid.

Het huidige I-See! produkt geeft informatie over 80 beroepsklassen (CBS-Beroepenclassificatie 2-digit niveau), op sommige onderdelen uitgesplitst naar 320 beroepsgroepen (3-digit niveau), en over 54 opleidingstypen (afgeleid uit de Standaard Onderwijs Indeling 3-digit niveau). Vanuit de gebruikers van I-See! is er een duidelijke wens om te komen tot een verdere verbijzondering van de informatie, zowel naar beroep als naar opleiding. In combinatie met de wens regiospecifieke informatie te verstrekken stelt dit erg hoge eisen aan de (omvang van de) hiervoor noodzakelijke databronnen. Daarbij is het niet op voorhand te zeggen op welk regionaal niveau de gewenste arbeidsmarktinformatie precies betrekking moet hebben. Richtsnoer is hierbij vanzelfsprekend de mate waarin de arbeidsmarkt daadwerkelijk regionaal is gesegmenteerd. Voor opleidingen en beroepen op MBO-niveau betekent dit dat informatie op provinciaal niveau waarschijnlijk al voldoende richtinggevend is. Op MAVO/LBO-niveau is een nog vergaande opsplitsing naar RBA-regio wenselijk.

De vertaalslag van de arbeidsmarktinformatie van I-See! naar het arbeidsvoorzieningsbeleid is momenteel nog onvoldoende uitgekristalliseerd. Ten aanzien van het directe bemiddelingsbeleid is de gebruikersbehoefte in belangrijke mate gericht op informatie over de actuele arbeidsmarktsituatie. Naast informatie over werkloosheid en vacatures, kan informatie over de uitwijkmogelijkheden naar beroep en/of branche hierbij van nut zijn, aangevuld met specifieke informatie over bepaalde marktsegmenten.

Voor het scholingsbeleid is inzicht in de verwachte arbeidsmarktontwikkeling naar beroep en opleiding, op basis van vraag- en aanbodprognoses, natuurlijk van groot belang. Doordat de tijdsduur van de scholingstrajecten in het kader van het arbeidsvoorzieningsbeleid doorgaans veel korter is dan de opleidingsduren in het initiële onderwijs, is de wenselijke prognosetermijn ook korter. Daarbij kan worden gedacht aan een prognosetermijn van één of twee jaar. Bij het arbeidsvoorzieningsbeleid gaat de behoefte uit naar informatie die in vergaande mate naar regio is verbijzonderd. De recent gecreëerde bestuursstructuur voor het arbeidsvoorzieningsbeleid maakt het RBA-niveau tot het meest geschikte niveau, waarop de vereiste regionale arbeidsmarktinformatie beschikbaar zou moeten komen. Ook hier geldt dat een vergaande differentiatie naar beroep en opleiding, dan momenteel bij de arbeidsmarktinformatie van I-See! plaatsvindt, is gewenst. 
Zowel ten aanzien van het bemiddelings-, als het scholingsbeleid bestaat er behoefte aan het toetsen van de effectiviteit van de diverse beleidsinstrumenten. Ook hierbij is het (arbeidsmarkt)bereik van de beleidsinstrumenten naar sector, beroep, opleiding en overige persoonskenmerken van belang. In schema 2.1. wordt een globaal overzicht gegeven van de gebruikersbehoeften ten aanzien van regionale arbeidsmarktinformatie vanuit de vier in het begin van dit hoofdstuk onderscheiden directe gebruiksdoelen. Voor wat betreft de aard van de gewenste informatie is een indeling gemaakt in respectievelijk prognoses, informatie over de actuele arbeidsmarktsituatie, risico-indicatoren en specifieke informatie over bepaalde arbeidsmarktsegmenten.

Naast de hierboven reeds beschreven informatiebehoefte vanuit de studie- en beroepskeuzevoorlichting en het arbeidsvoorzieningsbeleid, wordt in het schema ook een indicatie gegeven van de informatiebehoefte vanuit het onderwijs- en curriculumplanningsbeleid van overheden c.q. onderwijsinstellingen en het personeels- en wervingsbeleid van arbeidsorganisaties. Voor het onderwijsbeleid is informatie over de toekomstige arbeidsmarktperspectieven naar opleiding vooral van belang ten behoeve van de capaciteitsplanning. De risico-indicatoren kunnen op dit punt aanvullende informatie verschaffen. De meer specifieke informatie over de voor de desbetreffende opleidingen relevante arbeidsmarktsegmenten is vooral van belang voor de curriculumplanning en/of voor het initiëren van eventuele nascholingstrajecten. De behoefte aan regionaal verbijzonderde data is niet in alle gevallen evident. Vooral bij prognosecijfers is het belang van regionale data voor het onderwijsplanningsbeleid echter duidelijk aanwezig. De behoefte gaat daarbij doorgaans uit naar informatie, die binnen de opleidingstypen kan worden verbijzonderd naar de onderscheiden opleidingsrichtingen.

De diverse in schema 2.1. genoemde soorten informatie zijn ook van belang voor het personeelswervings- en -planningsbeleid van bedrijven, non-profit- en overheidsorganisaties. Daarbij gaat de wens uit naar regionale informatie verbijzonderd naar opleidingsrichting, met uitzondering van het Wetenschappelijk Onderwijs en eventueel ook het HBO, waarvan de werving van nieuw personeel doorgaans op landelijk niveau plaatsvindt. Ten aanzien van het LTO en MAVO wordt vanuit het bedrijfsleven vaak de wens naar voren gebracht, bij het arbeidsaanbod een onderscheid te maken tussen enerzijds de schoolverlaters op C/D-niveau en anderzijds de schoolverlaters op A/B-niveau.

Als algemene conclusie kan worden geformuleerd dat de gebruikersbehoefte ten aanzien van regionale arbeidsmarktinformatie vanuit de hierboven beschreven gebruiksdoelen groot is. 
Schema 2.1. Gebruiksdoelen en gebruikersbehoeften

\begin{tabular}{|c|c|c|c|c|c|}
\hline \multirow{3}{*}{ Gebruikersbehoeften } & \multicolumn{3}{|c|}{ Gebruiksdoelen } & \multirow{3}{*}{$\begin{array}{l}\text { Onderwijs- } \\
\text { en curri- } \\
\text { culumplan- } \\
\text { ning }\end{array}$} & \multirow{3}{*}{$\begin{array}{l}\text { Personeels- } \\
\text { wervings- en } \\
\text { planningsbe- } \\
\text { leid }\end{array}$} \\
\hline & Studie- en & Arbeidsv & ningsbeleid & & \\
\hline & & $\begin{array}{l}\text { bemid- } \\
\text { deling }\end{array}$ & scholing & & \\
\hline \multicolumn{6}{|l|}{ Prognoses } \\
\hline Aanbod naar opleiding & $x$ & & $x$ & $x$ & $x$ \\
\hline Vraag naar opleiding & $x$ & $x$ & $x$ & $x$ & $x$ \\
\hline $\begin{array}{l}\text { Arbeidsmarktsituatie } \\
\text { naar opleiding }\end{array}$ & $x$ & & $x$ & $x$ & $x$ \\
\hline $\begin{array}{l}\text { Job-openings naar } \\
\text { beroep }\end{array}$ & $x$ & & $x$ & & $x$ \\
\hline \multicolumn{6}{|l|}{$\begin{array}{l}\text { Actuele arbeidsmarkt- } \\
\text { situatie }\end{array}$} \\
\hline Werkloosheid & $x$ & $x$ & $x$ & $x$ & $x$ \\
\hline Vacatures & $x$ & $x$ & $x$ & $x$ & $x$ \\
\hline \multicolumn{6}{|l|}{ Risico-indicatoren } \\
\hline $\begin{array}{l}\text { Conjunctuurgevoelig- } \\
\text { heid werkgelegenheid }\end{array}$ & $x$ & $x$ & $x$ & $x$ & \\
\hline $\begin{array}{l}\text { Uitwijkmogelijkheden } \\
\text { naar beroep }\end{array}$ & $\mathrm{x}$ & $x$ & $x$ & $x$ & $X^{*}$ \\
\hline $\begin{array}{l}\text { Uitwijkmogelijkheden } \\
\text { naar branche }\end{array}$ & $x$ & $x$ & $x$ & $x$ & $X^{*}$ \\
\hline \multicolumn{6}{|l|}{$\begin{array}{l}\text { Specifieke informatie } \\
\text { over bep. } \\
\text { arbeidsmarkt- } \\
\text { segmenten }\end{array}$} \\
\hline Opleiding $x$ beroep & $x$ & $x$ & $x$ & $x$ & $x$ \\
\hline Opleiding $x$ branche & $x$ & $x$ & $\mathrm{x}$ & $x$ & $x$ \\
\hline Beroep $\times$ branche & $x$ & $x$ & $x$ & & $x$ \\
\hline Beroepsprofielen & $x$ & $x$ & $x$ & $x$ & $x$ \\
\hline $\begin{array}{l}\text { Scholing(sbehoefte) } \\
\text { schoolverlaters }\end{array}$ & & & $x$ & $x$ & $x$ \\
\hline $\begin{array}{l}\text { Zoekgedrag op de } \\
\text { arbeidsmarkt }\end{array}$ & & $x$ & & & $x$ \\
\hline $\begin{array}{l}\text { Effectiviteit beleids- } \\
\text { instrumenten }\end{array}$ & $\mathrm{x}$ & $x$ & $x$ & $x$ & $x$ \\
\hline
\end{tabular}

$X=$ belangrijke informatie

$x=$ nuttig als achterliggende informatie

*Bekeken vanuit de omgekeerde invalshoek 
$-8-$

Daarbij gaat het zowel om prognoses van de toekomstige arbeidsmarktsituatie, als om informatie over de actuele arbeidsmarktsituatie, risico-indicatoren en specifieke informatie over bepaalde arbeidsmarktsegmenten. Bovendien wordt een vergaande differentiatie naar de diverse opleidingsrichtingen binnen een bepaald opleidingstype in het algemeen als zeer wenselijk ervaren. Het is duidelijk dat dit alles hoge eisen stelt aan de (steekproefomvang van de) benodigde arbeidsmarktgegevens. Wat dit betreft zou met name de vraag kunnen worden gesteld, in hoeverre men voor specifieke informatie over bepaalde arbeidsmarktsegmenten (opleiding $\mathrm{x}$ beroep, opleiding $\mathrm{x}$ branche en beroep $\mathrm{x}$ branche) niet zou kunnen volstaan met landelijke gegevens, aangevuld met (rechte tellingen van) de regionale opleidingenstructuur, de regionale beroepenstructuur en de regionale bedrijvenstructuur. 


\section{BESCHIKBARE GEGEVENS OP REGIONAAL NIVEAU}

De beschikbaarheid van regionale arbeidsmarktgegevens op een niet al te hoog aggregatieniveau is in ons land helaas uiterst beperkt. Globaal gesproken kan worden gesteld dat de beschikbare informatie alleen toereikend is voor een verbijzondering naar bedrijfscategorie. De mogelijkheden voor een detaillering naar opleiding en beroep zijn daarentegen uiterst beperkt. Dergelijke differentiaties zijn vrijwel alleen mogelijk met de geregistreerde werkloosheidsdata en, voorzover beschikbaar, de vacaturecijfers van de arbeidsbureaus. Daarnaast zijn er op regionaal niveau ook gegevens beschikbaar over de uitstroom uit het onderwijs naar opleidingsrichting. Hieronder volgt een beknopt overzicht van de belangrijkste databronnen waaruit momenteel regionale arbeidsmarktinformatie kan worden geput, verbijzonderd naar bedrijf, beroep en opleiding ${ }^{1}$.

\section{Werkgelegenheidsontwikkeling}

Voor het in beeld brengen van de werkgelegenheidsontwikkeling is het noodzakelijk over informatie te beschikken over de werkzame beroepsbevolking. Een nuttige informatiebron op dit punt vormen de Regionale Economische Jaarcijfers (REJ) van het CBS, waarin een opsplitsing plaatsvindt naar 36 bedrijfsklassen. De REJ geven deze informatie zowel naar provincie, als naar COROP-regio. Daarbij wordt geen uitsplitsing gegeven naar beroep of opleiding.

De Enquête Regionale Bedrijfsontwikkeling (ERBO) van de Kamers van Koophandel en Fabrieken is een jaarlijks gehouden representatieve steekproef onder bedrijfsvestigingen. De respons is relatief hoog. De ERBO-enquête geeft informatie over de werkgelegenheid uitgesplitst naar bedrijfstakken. De gehanteerde sectorcodering is vrijwel identiek met de Standaard Bedrijfsindeling (SBI) van het CBS. Daarbij is een uitsplitsing mogelijk naar kleinbedrijf $1<50$ personen) en overige bedrijven. Eveneens is een onderscheid mogelijk naar banen met een werktijd van minder dan 15 uur per week en banen van 15 uur of meer per week. Bovendien wordt in de ERBO-enquête gevraagd naar de verwachte werkgelegenheidsontwikkeling voor het komend jaar. De ERBO-enquête geeft echter geen uitsplitsing van de werkgelegenheid naar beroep of opleiding. De Kamers van Koophandel verstrekken de informatie op provinciaal niveau en op het niveau van de Kamer van Koophandel-districten of subregio's daarvan.

De Kamers van Koophandel houden ook een Werkzame Personen Enquête. Deze enquête maakt een veel vergaande opsplitsing van de werkgelegenheid naar bedrijfsgroep of bedrijfssubgroep mogelijk dan de ERBO-enquête. Niet alle Kamers van Koophandel doen echter aan deze enquête

1. Zie ook Huson en Meesters (1989) en Arbeidsvoorziening (1990-I). 
mee.

De Statistiek Werkzame Personen van het CBS verschaft gegevens over het aantal banen naar bedrijfsklasse (SBI 2-digit) op provinciaal en RBA-niveau. Alhoewel de gegevens naar bedrijf op 4-digit niveau zijn gecodeerd, verschaft het CBS geen verder gedesaggregeerde gegevens dan de gepubliceerde data naar bedrijfsklasse.

Een verbijzondering van de werkzame bevolking naar beroep, opleiding, geslacht en leeftijd is wel mogelijk op basis van de grootschalige persoonsenquêtes van het CBS. Na de laatste Volkstelling van 1971, is er in de periode 1975-1985 tweejaarlijks een Arbeidskrachtentelling (AKT) gehouden. In 1987 is de AKT opgevolgd door een continue enquêtering op basis van de Enquête Beroepsbevolking (EBB). Uit de EBB kunnen jaarlijks arbeidsmarktgegevens worden verkregen op provinciaal, COROP- en RBA-niveau. Hoewel jaarlijks 132.000 adressen worden benaderd en de totale respons circa 133.000 personen betreft (waarvan circa 115.000 personen van 15-64 jaar) is een verfijning naar (bedrijfs)sector, beroep, opleiding ${ }^{2}$ of leeftijd op een laag regionaal niveau slechts in zeer beperkte mate mogelijk. Dit geldt in nog sterkere mate voor bepaalde kruisverbanden, als bijvoorbeeld de beroepenstructuur of de opleidingenstructuur van bedrijfstakken.

De tabellen 3.1. en 3.2. geven een beeld van de beschikbare informatie op provinciaal niveau over respectievelijk de beroepen- en de opleidingenstructuur van bedrijfstakken. Het gaat hierbij om gegevens naar bedrijfstak (SBI, 1-digit), beroepstak (CBS-Beroepenclassificatie, 1-digit) en opleidingsniveau (SOI, 1-digit) uit de AKT $1985^{3}$.

Wanneer we kijken naar de celvulling van met name de kleinere provincies (Groningen, Friesland, Drenthe, Flevoland en Zeeland) valt duidelijk te zien dat bij een verdere verfijning naar bedrijfsklasse, beroepsklasse, opleidingstype of RBA-regio de celvulling veel te klein wordt om nog op verantwoorde wijze uitspraken te kunnen doen over verschuivingen in de opleidingen- of beroepenstructuur van de sectorale werkgelegenheid ${ }^{4}$. Bovendien hanteert het CBS voor de EBB momenteel de regel dat slechts informatie aan derden wordt verstrekt bij een celvulling van minimaal 2500 personen. Wanneer een dergelijke celvulling niet wordt gerealiseerd, zal moeten

2. Overigens komen de EBB-gegevens naar opleiding pas voor het eerst beschikbaar over het jaar 1990.

3. Deze gegevens zijn ook beschikbaar voor de AKT 1981 en 1983.

4. Momenteel wordt in I-See! de arbeidsmarktinformatie verbijzonderd naar 20 bedrijfsklassen, 80 beroepsklassen en 54 opleidingstypen. Bij verschillende beroepsklassen en opleidingstypen wordt dit aggregatieniveau als te hoog ervaren. 
worden teruggevallen op een kostbaar deelbestand met individuele gegevens met daaraan verbonden gebruiksrestricties.

Tabel 3.1. Werkzame personen naar beroeps- en bedrijfstak (provincie Friesland), 1985

\begin{tabular}{|c|c|c|c|c|c|c|c|c|}
\hline & $\begin{array}{l}\text { Land- } \\
\text { bouw en } \\
\text { Visserij }\end{array}$ & $\begin{array}{l}\text { Delfst. } \\
\text { winning, } \\
\text { Industrie }\end{array}$ & Bouw & $\begin{array}{l}\text { Handel en } \\
\text { Horeca }\end{array}$ & $\begin{array}{l}\text { Transport, } \\
\text { Opslag en } \\
\text { Commun. } \\
\text { bedrijven }\end{array}$ & $\begin{array}{l}\text { Banken, } \\
\text { Verzeke- } \\
\text { ringen e.d. }\end{array}$ & $\begin{array}{l}\text { Overige } \\
\text { diensten }\end{array}$ & Totaal \\
\hline \multicolumn{9}{|c|}{$\times 1000$} \\
\hline $\begin{array}{l}\text { Wetenschappelijke e.a. } \\
\text { vakspecialisten, } \\
\text { kunstenaars }\end{array}$ & 0,2 & 3,5 & 1,1 & 0,6 & 1,0 & 2,4 & 26,2 & 35,1 \\
\hline $\begin{array}{l}\text { Beleidvoerende en } \\
\text { hogere leidinggeven- } \\
\text { de functies }\end{array}$ & 0,3 & 1,9 & 1,1 & 0,2 & 0,4 & 0,5 & 1,0 & 5,4 \\
\hline $\begin{array}{l}\text { Administratieve } \\
\text { functies }\end{array}$ & 0,3 & 4,4 & 1,0 & 3,7 & 3,3 & 8,1 & 8,8 & 29,5 \\
\hline $\begin{array}{l}\text { Commerciële } \\
\text { functies }\end{array}$ & - & 1,6 & 0,2 & 15,8 & 0,0 & 1,2 & 0,1 & 18,8 \\
\hline $\begin{array}{l}\text { Dienstverlenende } \\
\text { functies }\end{array}$ & - & 0,6 & 0,1 & 3,8 & 0,3 & 0,8 & 17,0 & 22,6 \\
\hline $\begin{array}{l}\text { Agrarische beroepen, } \\
\text { vissers e.d. }\end{array}$ & 16,1 & 0,8 & 0,1 & - & - & 0,0 & 0,5 & 17,5 \\
\hline $\begin{array}{l}\text { Ambachts-, industrie-, } \\
\text { transportberoepen en } \\
\text { verwante functies }\end{array}$ & 0,4 & 26,4 & 11,9 & 5,6 & 4,9 & 0,7 & 2,0 & 52,1 \\
\hline Militairen & - & - & - & - & - & - & 3,4 & 3,4 \\
\hline Totaal & 17,4 & 39,3 & 15,5 & 29,8 & 10,0 & 13,7 & 59,1 & 185,7 \\
\hline
\end{tabular}

Bron: CBS

Voor enkele bedrijfstakken zoals bijvoorbeeld de bouw en de grafische industrie is op regionaal niveau gedesaggregeerde arbeidsmarktinformatie beschikbaar bij de aan de desbetreffende bedrijfssector gelieerde onderzoekinstituten of -afdelingen. Uit deze bronnen kan echter alleen van enkele specifieke bedrijfssectoren een beter beeld van de werkgelegenheidsontwikkeling worden verkregen. 
Tabel 3.2. Werkzame personen naar geslacht, bedrijfstak en het niveau van het hoogst behaalde onderwijsdiploma (provincie Limburg), 1985

\begin{tabular}{|c|c|c|c|c|c|c|c|c|c|}
\hline & Mannen & & & & Vrouwen & & & & \\
\hline & $\begin{array}{l}\text { Basis- } \\
\text { onderwijs }\end{array}$ & $\begin{array}{l}\text { MAVO/ } \\
\text { LBO }\end{array}$ & $\begin{array}{l}\text { HAVO } \\
\text { VWO } \\
\text { MBO }\end{array}$ & $\begin{array}{l}\text { HBO } \\
\text { Wo }\end{array}$ & $\begin{array}{l}\text { Basis- } \\
\text { onderwijs }\end{array}$ & $\begin{array}{l}\text { MAVO/ } \\
\text { LBO }\end{array}$ & $\begin{array}{l}\text { HAVO } \\
\text { VWO } \\
\text { MBO }\end{array}$ & $\begin{array}{l}\text { HBO } \\
\text { WO }\end{array}$ & Totaal \\
\hline \multicolumn{10}{|c|}{ X1000 } \\
\hline $\begin{array}{l}\text { Landbouw en } \\
\text { Visserij }\end{array}$ & 1,9 & 5,2 & 6,5 & 0,1 & 1,1 & 3,5 & 1,3 & 0,2 & 20,1 \\
\hline $\begin{array}{l}\text { Delfstoffen- } \\
\text { winning }\end{array}$ & 0,3 & 0,4 & 0,2 & 0,2 & - & - & - & - & 1,1 \\
\hline Industrie & 17,1 & 27,4 & 28,3 & 8,8 & 3,3 & 5,7 & 3,8 & 1,0 & 97,0 \\
\hline $\begin{array}{l}\text { Openbare } \\
\text { nutsbedrijven }\end{array}$ & 0,3 & 0,6 & 1,7 & 0,4 & - & 0,1 & 0,2 & 0,0 & 3,3 \\
\hline Bouwnijverheid & 5,0 & 7,9 & 10,0 & 1,1 & 0,2 & 0,8 & 0,1 & 0,1 & 25,7 \\
\hline $\begin{array}{l}\text { Handel, hotel- } \\
\text { en restaurant- } \\
\text { wezen, repara- } \\
\text { tiebedrijuen }\end{array}$ & 4,6 & 9,0 & 17,3 & 1,6 & 4,4 & 11,9 & 7,8 & 0,4 & 58,5 \\
\hline $\begin{array}{l}\text { Transport-, } \\
\text { opslag- en } \\
\text { communicatie- } \\
\text { bedrijven }\end{array}$ & 3,5 & 6,4 & 6,3 & 0,8 & 0,2 & 1,0 & 1,4 & 0,1 & 19,7 \\
\hline $\begin{array}{l}\text { Bank- en verze- } \\
\text { keringswezen, } \\
\text { zakelijke dienst- } \\
\text { verlening }\end{array}$ & 0,6 & 2,0 & 8,7 & 4,6 & 0,4 & 2,8 & 5,1 & 1,0 & 25,5 \\
\hline $\begin{array}{l}\text { Overige dienst- } \\
\text { verlening }\end{array}$ & 2,7 & 9,0 & 66,3 & 23,3 & 6.4 & 13,5 & 25,6 & 14,2 & 116,3 \\
\hline Totaal & 36,0 & 68,0 & 99,6 & 41,1 & 16,0 & 39,5 & 45,6 & 17,1 & 370,4 \\
\hline
\end{tabular}

Bron: CBS

\section{Aanbod schoolverlaters}

De Integrale Leerlingtelling Dagonderwijs (ILLT) van het Ministerie van Onderwijs en Wetenschappen geeft jaarlijks informatie over onder meer het aantal gediplomeerden per opleidingsrichting van het voltijds voortgezet dagonderwijs. Deze gegevens worden per school verzameld en kunnen op basis van een schoolcode op ieder gewenst aggregatieniveau worden geregionaliseerd. De gegevens hebben echter betrekking op de vestigingsplaats van de scholen, hetgeen niet noodzakelijkerwijs hoeft overeen te stemmen met de woonregio's van de leerlingen. Hoewel de gehanteerde codes voor de onderscheiden opleidingsrichtingen afwijken 
van de Standaard Onderwijs Indeling (SOI) van het CBS, is het wel mogelijk de gegevens tot deze CBS-code te herleiden.

De Integrale Leerlingtelling Beroepsbegeleidend Onderwijs (OVL) van het Ministerie van Onderwijs en Wetenschappen bevat informatie over de leerlingen in het leerlingwezen, het (deeltijd-) KMBO e.d.. Hier is het wel mogelijk op basis van de woonplaats van de leerlingen de gegevens op ieder gewenst aggregatieniveau te regionaliseren. Bovendien is het mogelijk de gegevens te vertalen naar de SOI.

Voor de jaren 1982 en 1985 heeft het CBS regionale onderwijsmatrices gepubliceerd, waaruit voor het voltijds dagonderwijs de uitstroom per woonregio kan worden afgeleid. De regionalisatie heeft daarbij echter betrekking op 25 clusters van nodale gebieden, die echter niet eenduidig vertaalbaar zijn naar provinciaal niveau of RBA-regio's. De gegevens hebben betrekking op opleidingstypen en zijn slechts op indirecte wijze te vertalen naar de SOI. In hoeverre de uitstroom uit het voltijds dagonderwijs ook daadwerkelijk leidt tot een instroom op de arbeidsmarkt kan op basis van deze gegevensbron niet nauwkeurig worden vastgesteld. Voor 1988 heeft het CBS geen regionale onderwijsmatrix gepubliceerd. Het is op dit moment nog onduidelijk in hoeverre voor 1991 een dergelijke publicatie zal verschijnen.

Naast de feitelijke gegevens over de uitstroom uit het onderwijs zijn er ook prognoses voorhanden van deze uitstroom, verbijzonderd naar regio. Voor het hoger onderwijs worden vanuit het Ministerie van Onderwijs en Wetenschappen prognoses opgesteld van de gediplomeerde uitstroom per studierichting op instellingsniveau (RIHBOS en WORSA voor respectievelijk het $\mathrm{HBO}$ en WO), op basis waarvan de gegevens op ieder gewenst regionaal niveau kunnen worden geaggregeerd. Zeker voor het Hoger Beroepsonderwijs kan het als een belangrijke tekortkoming worden beschouwd dat deze gegevens niet betrekking hebben op de woonregio van de afgestudeerden.

INRO/TNO stelt jaarlijks in opdracht van het Ministerie van Onderwijs en Wetenschappen prognoses op van de leerlingenaantallen (op lager en middelbaar niveau) per regio. Deze zogenaamde PRUSO-ramingen hebben betrekking op 81 nodale gebieden en worden daarnaast voor enkele prognosejaren ook op provincieniveau berekend. Naast een opsplitsing naar regio op basis van de vestigingsplaats van de scholen, wordt er ook een opdeling gemaakt naar de woonregio's van de leerlingen. In totaal worden 18 opleidingstypen onderscheiden die vertaalbaar zijn naar de binnen I-See! onderscheiden opleidingstypen. Voor het AVO vindt er bovendien een uitsplitsing naar leerjaar plaats. 


\section{Aanbod werklozen}

Op basis van het bemiddelingsbestand zonder baan (BZB) van de arbeidsvoorzieningsorganisaties kan via de gemeentecode op ieder gewenst regionaal niveau het aanbod van werklozen naar (gewenst en/of vorig) beroep en opleiding in beeld worden gebracht. Probleem daarbij is wel de zogenaamde 'vervuiling' van dit databestand. Een ander probleem dat zich hierbij voordoet, is dat de gehanteerde AROI-opleidingscodes niet altijd eenduidig koppelbaar zijn met de opleidingscodes van het CBS. Een soortgelijke probleem, maar dan in nog sterkere mate, speelt bij de beroepencodes (ARBI versus CBS-Beroepenclassificatie).

Bovendien kan het bestand slechts een beeld geven van de absolute aantallen werklozen. Voor het vaststellen van de ernst van de werkloosheid naar opleiding en beroep is het noodzakelijk de werkloosheidsdata te relateren aan het totaal aantal werkenden met de desbetreffende opleiding c.q. het desbetreffende beroep. Wel is het mogelijk de werkloosheidsgegevens te verbijzonderen naar bijvoorbeeld geslacht, leeftijd, (de mate van) langdurige werkloosheid en schoolverlaters.

Her-om- en bijscholing

Ten aanzien van de scholingsmaatregelen van de arbeidsvoorzieningsorganisaties zijn gegevens beschikbaar over de aantallen deelnemers aan cursussen van de Centra voor Beroepsoriëntatie en Beroepsoefening (CBB) en de Centra voor (Administratieve) Vakopleiding voor Volwassenen $(C(A) V V)$. Deze gegevens worden per instelling verzameld. Deelnamegegevens over de Kaderregeling Scholing (KRS) worden per project verzameld.

\section{Vacatures}

Van de arbeidsvoorzieningsorganisaties kunnen op regionaal niveau gegevens worden verkregen over het aantal geregistreerde vacatures. Het betreft hier echter slechts een beperkt deel van het werkelijke aantal vacatures. De dekking van de Vacature-enquête van het CBS is vollediger. Deze enquête verschaft onder meer gegevens over het totale aantal vacatures, het aantal moeilijk vervulbare vacatures, het aantal vacatures voor schoolverlaters en het aantal vervulde vacatures. De vacatures in enkele belangrijke sectoren (overheid, onderwijs en vacatures bij uitzendbureaus) vallen echter buiten deze enquête. Hoewel de vacatures op een niet al te hoog aggregatieniveau zijn gecodeerd naar bedrijf, beroep en opleiding en ook kunnen worden opgesplitst naar bijvoorbeeld provincie of RBA-regio, is een regionalisering van de cijfers vanwege de beperkte omvang van de steekproef slechts in zeer beperkte mate mogelijk (zie tabel 3.3.). 
Tabel 3.3. Aantal vacatures en moeilijk vervulbare vacatures naar provincie 1982 en 1989

\begin{tabular}{lcccc}
\hline Provincie & & Vacatures & & \multicolumn{2}{c}{ Waarvan moeilijk vervulbaar } \\
& 1982 & 1989 & 1982 & 1989 \\
\hline Groningen & 0,5 & $\times 1000$ & & 1,1 \\
Friesland & 0,6 & 2,3 & 0,1 & 0,7 \\
Drenthe & 0,3 & 1,4 & 0,1 & 0,7 \\
Overijssel & 0,8 & 1,6 & 0,1 & 1,6 \\
Flevoland & - & 4,3 & 0,2 & 0,4 \\
Gelderland & 1,8 & -1 & 4,2 \\
Utrecht & 1,5 & 8,8 & 0,5 & 3,4 \\
Noord-Holland & 4,4 & 6,9 & 0,3 & 8,8 \\
Zuid-Holland & 4,0 & 18,8 & 1,2 & 13,4 \\
Zeeland & 0,3 & 23,8 & 1,1 & 0,7 \\
Noord-Brabant & 2,5 & 1,5 & 0,2 & 7,5 \\
Limburg & 1,1 & 14,0 & 0,6 & 4,3 \\
\hline
\end{tabular}

Bron: CBS

\section{Pendel en Migratie}

Het Onderzoek verplaatsingsgedrag van het CBS levert jaarlijks gegevens op over de in- en uitgaande pendel op provincieniveau. Daarbij wordt echter noch naar bedrijfssector, noch naar beroep of opleiding gedifferentieerd. Ook uit de reeds genoemde Enquête Beroepsbevolking worden pendelgegevens afgeleid, maar hier wordt (nog) niet over gepubliceerd. Alhoewel een uitsplitsing naar bedrijfssector, beroep en opleiding daarbij in principe mogelijk is, is de steekproefomvang waarschijnlijk te gering, om dergelijke opsplitsingen daadwerkelijk te kunnen realiseren.

Op basis van gegevens uit de bevolkingsregisters publiceert het CBS jaarlijks op gemeenteniveau over de omvang van de migratiestromen. Ook hierbij is een opsplitsing van de migratiestromen naar bedrijfssector, beroep of opleiding niet mogelijk.

\section{Andere relevante informatie}

Ook andersoortige informatie kan van belang zijn voor het in beeld brengen van regionale arbeidsmarktontwikkelingen. Daarbij kan met name worden gedacht aan informatie over grootheden die gebruikt worden als 'verklarende variabelen' in prognosemodellen (zie b.v. 
Arbeidsvoorziening, 1990-II). Zo verschaft het CBS informatie over de investeringen in vaste activa naar bedrijfstak (1-digit) ${ }^{5}$ en de toegevoegde waarde naar bedrijfstak op provinciaal en op COROP-niveau. Ook wordt een opsplitising gegeven van het aantal bedrijven in een bedrijfstak naar bedrijfsgrootte. Andere in dit verband mogelijk nuttige regionale informatie betreft de leeftijdssamenstelling van de bevolking, de woningbouw en de woningbehoefte, de beschikbaarheid en prijs van bedrijfsterreinen en attractiefactoren van het woonmilieu.

5. Voor de industrie op provinciaal niveau uitgesplitst naar bedrijfsklassen (2-digit). 


\section{ENKELE RECENTE INITIATIEVEN}

\subsection{Een negental initiatieven}

Wanneer we de enorme behoefte aan regionale arbeidsmarktinformatie relateren aan de uiterst beperkte aanwezigheid van dergelijke informatie, is het niet verbazingwekkend dat er recentelijk diverse initiatieven zijn ontwikkeld om te komen tot een verbetering van het aanbod van regionale arbeidsmarktinformatie. In dit hoofdstuk zullen een aantal van dergelijke initiatieven nader worden besproken. De initiatieven worden daarbij ingedeeld in een drietal categorieën ${ }^{6}$ :

- initiatieven gericht op het herordenen van bestaande informatie en het vergroten van de toegankelijkheid van deze informatie;

- meetinstrumenten op basis waarvan nieuwe arbeidsmarktinformatie beschikbaar komt;

- statistische of econometrische modellen met behulp waarvan regionale data en prognoses kunnen worden gegenereerd.

Herordenen bestaande informatie

De eerste categorie initiatieven die we kunnen onderscheiden, wordt gevormd door de pogingen om met enkele eenvoudige bewerkingen de toegankelijkheid van reeds bestaande gegevensbronnen te vergroten, zodat de regionale arbeidsmarkt voor de beoogde doelgroep(en) meer transparant wordt gemaakt. Het betreft hier veelal de ontwikkeling van indicatoren die er op gericht zijn beleidsfunctionarissen e.d. in staat te stellen op eenvoudige wijze gebruik te maken van de beschikbare arbeidsmarktinformatie. Op een drietal van dergelijke indicatoren zal hieronder worden ingegaan.

\section{Methodiek scholingsplanning}

In het kader van de Methodiek scholingsplanning is de afgelopen jaren een planningsmethodiek ontwikkeld voor een fasegewijs vanuit de praktijk te ontwikkelen arbeidsmarktinformatiesysteem ten behoeve van de arbeidsvoorzieningsorganisatie (Mul, Meijer en Van Ham, 1990). Het doel van deze methodiek scholingsplanning is om op jaarbasis te komen tot de vaststelling van de regionale scholingsvraag in een samenhangend stelsel van planningsprocedures. De methodiek is bedoeld als een hulpmiddel voor de arbeidsbureaus en daarmee als een beleidsonderbouwend instrument voor de besturen van de regionale

6. Strikt genomen passen enkele initiatieven niet geheel binnen een van deze drie categorieën. In dat geval zijn ze ingedeeld bij de categorie die hen het beste karakteriseert. 
arbeidsvoorzieningsorganisaties. Daarbij staat centraal het traceren van de ontwikkelingstrends in de bij het eigen arbeidsbureau bekende vacaturecijfers van de meest voorkomende beroepen met als doel een inschatting te maken van de vacatures die binnen een termijn van één tot twee jaar te verwachten zijn. Daarnaast wordt gedacht aan het opzetten van een signaleringsmethodiek, waarbij gebruik gemaakt wordt van landelijke en regionale informatie, met name verbijzonderd naar bedrijfssector. Hiervoor wordt gedacht aan het verzamelen en interpreteren van CPB-prognoses, sectorstudies, C.A.O.-afspraken over scholing, rapporten over beroepsprofielen, contacten met branche-organisaties en vakbonden e.d.. Daarnaast zal ook de ontwikkelingstrend van het arbeidsaanbod, in de zin van de ingeschreven werkzoekenden, in kaart moeten worden gebracht. Door het verwachte aanbod te vergelijken met de verwachte vraag naar een bepaalde beroepscategorie, moet een indicatie worden verkregen van de scholingsbehoefte voor de desbetreffende beroepsgroep. Alvorens tot een definitieve bepaling van de scholingsbehoefte voor een bepaald beroep te komen, moet ook de instroom van voor het beroep relevante categorieën schoolverlaters op de arbeidsmarkt in beeld worden gebracht. De instroom van schoolverlaters zal daarbij moeten worden gespecificeerd naar beroep, opleidingsniveau en opleidingsrichting ${ }^{7}$.

\section{Gezamenlijk onderzoekprogramma onderwijs-arbeid Zuid-Holland}

Op initiatief van de provincie Zuid-Holland en de beide Contactcentra Onderwijs Arbeid (COA's) in deze provincie, is recentelijk de aanzet gegeven tot een gezamenlijk onderzoekprogramma dat als doel heeft een permanent informatiesysteem onderwijs-arbeidsmarkt op te bouwen, verbijzonderd naar RBA-regio. Het informatiesysteem zal worden samengesteld op basis van de potentieel beschikbare arbeidsmarktgegevens van de provincie, arbeidsbureaus, Kamers van Koophandel, COA's e.d. ${ }^{8}$. Door deze gegevens met elkaar te combineren en zonodig op eenvoudige wijze te bewerken wordt er naar gestreefd op een snelle en efficiënte manier onderzoekvragen van verschillende instellingen te kunnen beantwoorden.

Momenteel wordt er een vooronderzoek uitgevoerd naar de realiseerbaarheid van een dergelijk gezamenlijk onderzoekprogramma en het van daar uit op te zetten informatiesysteem. Er wordt met name nagegaan welke instellingen willen participeren in een dergelijk gezamenlijk onderzoekprogramma, welke onderzoek- of beleidsvragen met behulp van het informatiesysteem beantwoord moeten worden, welke route bij de opbouw van het systeem moet worden gevolgd

7. Daarvoor zou men gebruik willen maken van de RUVO-prognoses van INRO/TNO, die hieronder zullen worden besproken.

8. Het is uitdrukkelijk de bedoeling daarbij ook gebruik te maken van de RUBSschoolverlatersenquête, waarop hieronder zal worden ingegaan. 
en hoe het systeem organisatorisch moet worden ingekaderd.

\section{Monitor lokale arbeidsmarkt: AMSA}

Door de afdeling Sociaal-Geografisch en Bestuurskundig Onderzoek van de Vereniging van Nederlandse Gemeenten (VNG-SGBO) in samenwerking met NSS Beleidsonderzoek \& Beleidsadvies, is recentelijk vooronderzoek verricht naar de mogelijke invulling en de realiseerbaarheid van een plan voor de ontwikkeling van een permanent beleidsinstrument gericht op een arbeidsmarktsituatie-analyse (AMSA). Doel van deze voorstudie is het verkrijgen van inzicht in de behoefte van potentiële gebruikers aan een dergelijk beleidsondersteunend instrument en hun betrokkenheid bij de ontwikkeling van het instrument. Bij de potentiële gebruikers wordt daarbij gedacht aan RBA's, arbeidsbureau's, gemeenten, in het bijzonder de gemeentelijke sociale diensten en afdelingen verantwoordelijk voor werkgelegenheidsprojecten, Gemeenschappelijke Medische Dienst en dergelijke.

Doelstelling van het project is het ontwikkelen van een beleidsinstrument waarmee de beoogde doelgroepen op lokaal en regionaal niveau op systematische wijze inzicht kunnen krijgen in facetten van vraag en aanbod in de (beleidsvoering op het gebied van) de regionale en lokale arbeidsmarkt. AMSA beoogt daarbij niet kant-en-klare oplossingen aan te bieden, maar vooral een betere koppeling te maken tussen gegevens en beleid. Daarbij wordt gedacht aan het verstrekken van informatie over de vraag naar en het aanbod van arbeid en de daarbij optredende fricties, de werking van beleidsinstrumenten, het bereik van voorzieningen en de bestaande samenwerkingsverbanden op de arbeidsmarkt.

AMSA zal bovendien protocollen en scenario's bevatten, die aangeven op welke wijze benodigde gegevens voor de arbeidsmarktsituatie-analyse kunnen worden verzameld en welke knelpunten daarbij aanwezig kunnen zijn. Daarbij moet zoveel mogelijk gebruik worden gemaakt van reeds bestaande gegevensverzamelingen, waarover regionale en lokale actoren beschikken. Voorbeelden hiervan zijn registraties van arbeidsbureau's, uitzendbureau's, bedrijfsverenigingen, sociale dienst, scholings- en andere instellingen. Daarnaast worden mogelijkheden aangegeven om uit andere bronnen relevante gegevens te putten. Te denken valt onder meer aan databestanden van (onderzoek)projecten als 'Hoe zoeken werkzoekenden' en 'Hoe werven bedrijven', het GSD-panel, onderzoekactiviteiten op het terrein van sociale vernieuwing, RUBS enzovoort. Deze gegevensbestanden zullen ook informatie kunnen opleveren over specifieke doelgroepen van het arbeidsmarktbeleid, zoals langdurig werklozen, allochtonen, herintredende vrouwen, arbeidsongeschikten en specifieke beroepsgroepen. Naast het gebruik van kwantitatieve informatie, zal bij gebrek hieraan of ter nuancering hiervan ook worden gewezen 
op de kwalitatieve informatiebronnen.

De gebruikers zullen met behulp van AMSA in staat moeten zijn zelfstandig en in korte tijd een diagnose te maken van de situatie op de regionale of lokale arbeidsmarkt, zonder daarbij de hulp te moeten inschakelen van een extern gespecialiseerd onderzoekbureau. Het beoogde eindprodukt is te beschouwen als een soort handleiding, met aanwijzingen hoe zaken met betrekking tot de lokale en regionale arbeidsmarktproblematiek uitgezocht kunnen worden. Hierbij valt te denken aan onder andere een itemlijst waarin een volledig overzicht wordt gegeven van alle aspecten die bij het analyseren van de regionale en lokale arbeidsmarkt van belang zijn. Deze worden vervolgens uitgesplitst naar de verschillende deelterreinen van vraag, aanbod, scholing en bemiddeling, waarbij een overzicht wordt gegeven van alle relevante informatiebronnen. Bovendien zal een model worden ontwikkeld waarmee duidelijk wordt welke indicatoren voor verschillende beleidsterreinen van beslissende betekenis zijn en hoe de relatie ligt tussen bepaalde indicatoren en verschillende beleidsopties, om op basis daarvan tot besluitvorming te komen.

\section{Nieuwe meetinstrumenten}

De tweede categorie initiatieven probeert de bestaande lacunes in de beschikbare regionale arbeidsmarktinformatie op te vullen door het ontwikkelen van een of meer nieuwe meetinstrumenten. Ook hier zullen we een drietal van dergelijke initiatieven nader beschrijven.

\section{Modulair informatie-instrument}

Door een samenwerkingsverband van het Nederlands Instituut voor de Publieke Opinie en het Marktonderzoek (NIPO), het Economisch Instituut voor het Midden- en Kleinbedrijf (EIM) en het Bureau voor Economische Argumentatie (BvEA) wordt momenteel een modulair informatieinstrument voor het arbeidsvoorzieningsbeleid op de markt gebracht, waarmee actuele arbeidsmarktgegevens ten behoeve van de beleidsplanning kunnen worden verkregen en de effectiviteit van het gevoerde beleid kan worden gemeten. Het onderzoekpakket bestaat uit elf op zich zelf staande modules die tezamen een overall beeld geven van de actuele arbeidsmarktsituatie in een RBA-regio. Het gaat daarbij om de volgende modules: omgeving van de arbeidsmarkt, basiskenmerken van vraag en aanbod, toekomstige vraag, scholingsactiviteiten bedrijfsleven, marktaandelen van de wervingskanalen van bedrijven, knelpunten en trends op de arbeidsmarkt, doelgroepenbeleid en meting van effectiviteit en doelmatigheid.

De meeste modules zijn gebaseerd op een meting door middel van een telefonische enquête. Zo 
zal de toekomstige vraag in beeld worden gebracht door een telefonische enquête onder 500 bedrijven in de regio. Daarbij zal worden nagegaan wat het aantal bedrijven is met vacatures, wat de aard is van de vacatures en wat de omvang is van de personeelsuitstroom. Ook de omvang van de scholingsactiviteiten en de marktaandelen van de wervingskanalen zullen op basis van een telefonische enquête onder 500 bedrijven in de regio in kaart worden gebracht. De onderzoekmodule gericht op het traceren van de basiskenmerken van het aanbod bestaat uit een telefonische enquête onder 1000 personen uit de doelgroep, aangevuld met een analyse van de bestanden van de arbeidsbureau's, de GSD en de GMD.

Voor het vaststellen van de omvang van het aanbod van schoolverlaters wil men gebruik maken van de RUBS-enquête, waarop hierna verder zal worden ingegaan. In de laatste drie van de hierboven genoemde modules zal de vanuit de diverse meetinstrumenten verkregen informatie verder worden geanalyseerd, waarbij ook gebruik wordt gemaakt van reeds bestaande informatie. Kenmerkend daarbij is het gebruik van de NIPO Business-monitor en de toespitsing van de analyse op bepaalde bedrijfstakken.

\section{RUBS}

Door de Landelijke Commissie voor de Algemene Studievoorlichting (LCAS) en de COA's is enkele jaren geleden een initiatief ontwikkeld voor een landelijke schriftelijke schoolverlatersenquête: Registratie van de Uitstroom en de Bestemming van Schoolverlaters (RUBS). In 1989 is door het projectteam dat werd gecoördineerd door het ROA en wetenschappelijk ondersteund door het RION een meetinstrument ontwikkeld waarmee zeer specifieke informatie kan worden verkregen over de eerste bestemming van schoolverlaters op de arbeidsmarkt. Diverse aspecten van de aansluitingsproblematiek kunnen daarbij worden belicht: de relatieve omvang van de werkloosheid, de beroepen en bedrijfsgroepen waarin men werk vindt, de wijze waarop men aan een baan is gekomen, de beloning, de eventuele aanvullende scholing die men volgt en de zogenaamde 'kwalitatieve aansluitingsproblemen' tussen de gevolgde opleiding en de functie die men uitoefent. Door er voor te zorgen dat de gehanteerde classificaties van bedrijven, beroepen en opleiding vertaalbaar zijn naar de CBSclassificaties zijn de uitkomsten van de RUBS-enquête koppelbaar aan de diverse CBSstatistieken en de ERBO-enquête.

Voorgesteld is om de RUBS-enquête op permanente basis te organiseren in de vorm van een integrale enquêtering of een roterend panel van scholen waarbij jaarlijks circa 110.000-150.000 gediplomeerde en 40.000-60.000 ongediplomeerde schoolverlaters worden geënquêteerd. Een dergelijke opzet zou het mogelijk maken op een zeer laag aggregatieniveau van opleidingen een 
integraal beeld te krijgen van de kwalitatieve en kwantitatieve aansluiting tussen opleiding en werk in de diverse RBA-regio's. Zowel binnen het CBA als het Ministerie van Onderwijs en Wetenschappen wordt momenteel nagegaan of een dergelijke grootschalige schoolverlatersenquête in ons land zou kunnen worden gerealiseerd. Vooruitlopend daarop exploiteren op dit moment de gezamenlijke COA's de RUBS-enquête op een veel kleinere schaal, waarbij alle COA's elk jaar minimaal de schoolverlaters van éen bepaald opleidingstype enquêteren. In de provincie Zuid-Holland maakt de RUBS-enquête deel uit van het eerder beschreven gezamenlijke onderzoekprogramma.

\section{Functie-informatiesysteem}

Binnen de Gemeenschappelijke Medische Dienst (GMD) is de laatste jaren gewerkt aan de opbouw van het zogenaamde 'functie-informatiesysteem'. Dit systeem bevat informatie op bedrijfsniveau over de in het bedrijf voorkomende functies (momenteel van circa 5000 functies). Het gaat daarbij om informatie over zowel het aantal arbeidsplaatsen per functiecategorie, als de aard van de functie (inhoud, niveau, werkbelasting, werkomstandigheden, verdiensten, e.d.) en de openstaande vacatures. Doordat de gegevens naar zowel bedrijf als beroep koppelbaar zijn aan de bestaande CBS-codes, is het bij een verdere uitbouw van dit informatiesysteem mogelijk op een laag aggregatieniveau naar beroep en bedrijf informatie te verstrekken over de omvang van de werkgelegenheid en de ontwikkeling daarvan in het recente verleden. Van de werkgelegenheid(sontwikkeling) naar opleiding kan een indicatie worden verkregen op basis van de voor de diverse functies vereiste opleiding. Daarbij worden enkele tientallen verschillende opleidingstypen onderscheiden. In principe is het mogelijk al deze informatie ook op RBA-niveau te verstrekken.

Het systeem maakt het voor de GMD mogelijk de vacature-informatie te matchen met de ingeschreven arbeidsongeschikten. Tevens zou het systeem informatie moeten kunnen verschaffen over het aantal gerealiseerde plaatsingen en de daarvoor benodigde opleidingen. Hoewel het functie-informatiesysteem in eerste instantie is opgezet ten behoeve van de arbeidsongeschiktenbeoordeling en de arbeidsbemiddeling van arbeidsongeschikten door de GMD zelf, is de GMD bereid de beschikbare arbeidsmarktinformatie tegen vergoeding aan derden te leveren.

Statistische of econometrische modellen

De derde categorie initiatieven om te komen tot regionale arbeidsmarktinformatie, zijn de initiatieven om met behulp van statistische of econometrische modellen regionale 
arbeidsmarktdata en/of -prognoses te genereren. Ook hier bespreken we een drietal initiatieven.

\section{Regionale prognoses sectorale werkgelegenheid, beroepsbevolking en werkloosheid}

Hoewel strikt genomen niet gesproken kan worden van een recent initiatief, zijn door de Sector Onderzoek Arbeidsmarktvraagstukken (OAV) van de centrale arbeidsvoorzieningsorganisatie onlangs, met behulp van het door het Centraal Planbureau ontwikkelde REGAMBEV model, regionale prognoses opgesteld van de werkgelegenheidsontwikkeling in arbeidsjaren, verbijzonderd naar 13 bedrijfstakken, voor de periode 1990-1995 (Arbeidsvoorziening, 1990-II). De gegevens hebben momenteel nog betrekking op 11 provincies; gestreefd wordt naar een verbijzondering van de prognoses tot op het RBA-niveau.

Tevens is een prognose opgesteld van de bevolking en het arbeidsaanbod op provinciaal niveau. In combinatie met de prognose van de werkgelegenheidsontwikkeling in de desbetreffende provincie wordt een prognose gegeven van de ontwikkeling van de werkloosheid (werkzoekenden zonder baan) op provinciaal niveau. Het gaat hierbij alleen om de ontwikkeling van de totale werkloosheid.

De prognoses hebben primair als doel het Centraal Bestuur voor de Arbeidsvoorziening (CBA) van informatie te voorzien ten behoeve van de centrale beleidsplanning en daarnaast de RBA's te informeren over de regionale werkgelegenheids- en werkloosheidsverwachtingen.

\section{Regionale uitstroom voortgezet onderwijs}

In aansluiting op de in hoofdstuk 3 genoemde PRUSO-ramingen heeft INRO/TNO in opdracht van Arbeidsvoorziening recentelijk prognoses opgesteld van de uitstroom van schoolverlaters uit het voltijds voortgezet onderwijs per RBA-regio voor de schooljaren 1990-'91 tot en met 2000'01 (Vermeulen, 1990). Bij dit Regionalisering uitstroom voortgezet onderwijs (RUVO) project wordt de uitstroom van schoolverlaters van het LBO, AVO en MBO verbijzonderd naar 15 opleidingstypen. Daarbij wordt bovendien onderscheid gemaakt tussen mannen en vrouwen en tussen de gediplomeerde en ongediplomeerde uitstroom. Als de aantallen schoolverlaters van het desbetreffende opleidingstype in een bepaalde RBA-regio niet al te klein zijn, vindt bij de opleidingstypen LTO, LHNO, MTO, MEAO en MDGO bovendien nog een uitsplitsing plaats naar vakrichting. De prognoses hebben betrekking op het woongebied van de schoolverlaters. Zoals reeds werd opgemerkt hebben de prognoses alleen betrekking op de uitstroom uit het voltijds onderwijs. Met verschuivingen in het opleidingsprofiel van het (potentiële) arbeidsaanbod door het volgen van deeltijdonderwijs wordt derhalve (vooralsnog) geen rekening gehouden. 


\section{Regionaal informatiesysteem onderwijs-arbeidsmarkt}

Mede met het oog op het regionaliseren van de huidige arbeidsmarktinformatie van I-See!, wordt momenteel binnen het ROA geprobeerd de landelijke arbeidsmarktinformatie die in het huidige I-See! produkt wordt verstrekt, te verbijzonderen naar regio. Daarbij wordt in aansluiting op de in hoofdstuk 2 beschreven informatiebehoefte gedacht aan een regionalisering van zowel de actuele arbeidsmarktinformatie als de risico-indicatoren en de arbeidsmarktprognoses. Door de beperkte regionale desaggregatiemogelijkheden van het thans beschikbare datamateriaal wordt vooralsnog gestreefd naar het verbijzonderen van de arbeidsmarktinformatie naar provincie. Ook op dit aggregatieniveau zal het waarschijnlijk niet mogelijk zijn voor alle onderscheiden beroepsklassen en opleidingstypen arbeidsmarktinformatie te geven. Slechts op een enkel onderdeel zal een uitsplitsing naar RBA-regio mogelijk zijn. Zo is recentelijk door het ROA, met behulp van de INRO/TNO prognoses van schoolverlaters, een tweetal werkloosheidsindicatoren berekend op RBA-niveau voor 16 opleidingstypen (Beekman en De Grip, 1991).

\subsection{Betekenis voor het informatiesysteem I-See!}

Hoewel enkele van de in paragraaf 4.1. genoemde initiatieven sterk gericht zijn op een specifieke gebruikersbehoefte, zouden alle initiatieven in principe voor meer gebruiksdoelen tegelijk van nut kunnen zijn. Om hiervan een indruk te krijgen, zal ter illustratie worden aangegeven in hoeverre de genoemde initiatieven een bijdrage kunnen leveren aan het regionaliseren van de arbeidsmarktinformatie binnen het I-See! informatiesysteem van het LDC.

Het meest toegesneden op de behoefte van I-See! zijn de bij de nieuwe meetinstrumenten genoemde RUBS-schoolverlatersenquête en het functie-informatiesysteem van de GMD. De RUBS-schoolverlatersenquête zou met name een belangrijke bijdrage kunnen leveren aan een verdere verfijning van de arbeidsmarktinformatie naar zowel opleidingsrichting als regio (zie ook De Grip, Van der Velden en Wieling, 1991). De RUBS-gegevens maken het bijvoorbeeld mogelijk op regionaal niveau een veel nauwkeuriger beeld te geven van de uitwijkmogelijkheden op de arbeidsmarkt voor schoolverlaters met een bepaalde opleidingsachtergrond en van de relatie vakrichting-beroep, dan op basis van het momenteel beschikbare CBS-datamateriaal zou kunnen. Ook kan op regionaal niveau een beter beeld worden verkregen van de relatieve omvang van de werkloosheid van schoolverlaters, de beginsalarissen en de kwalitatieve aansluitingsproblemen. Tenslotte vormen de RUBS-gegevens een belangrijke informatiebron voor het opstellen van in I-See! op te nemen regionale prognoses van de arbeidsmarktperspectieven van opleidingen en beroepen. 
Het functie-informatiesysteem van de GMD zou een rijke informatiebron kunnen vormen voor de beroepsprofielen binnen I-See!. Daarnaast kan de GMD-informatie een verfijning van de werkgelegenheidsinformatie naar beroep op RBA-niveau mogelijk maken. Dit geldt zowel voor de actuele informatie als voor de prognoses.

Ook de onder de categorie 'statistische of econometrische modellen' beschreven initiatieven kunnen een belangrijke bijdrage leveren aan het regionaliseren van I-See!. De onder deze categorie genoemde drie initiatieven zijn bovendien in sterke mate complementair. De Arbeidsvoorziening (OAV) prognoses van de sectorale werkgelegenheid zouden daarbij de basis kunnen vormen van de regionale werkgelegenheidsprognoses, welke door het ROA verder zouden kunnen worden verbijzonderd naar beroeps- en opleidingscategorie. Een confrontatie van de job-openings naar opleidingstype met de prognoses van de uitstroom van schoolverlaters van INRO/TNO, indien mogelijk aangevuld met prognoses van de uitstroom uit het deeltijdonderwijs, zou het vervolgens mogelijk maken een typering te geven van de arbeidsmarktperspectieven op regionaal niveau naar opleidingstype. Een probleem dat zich daarbij zal voordoen is dat op basis van de momenteel beschikbare gegevensbronnen het niet mogelijk is op verantwoorde wijze op RBA-niveau prognoses op te stellen van de ontwikkeling van de werkgelegenheid en de vervangingsvraag. De prognoses die worden gemaakt door Arbeidsvoorziening (OAV) en het ROA zullen daarom vooralsnog betrekking hebben op het provinciaal niveau. Dit in tegenstelling tot de INRO/TNO prognoses van de aanbodzijde van de arbeidsmarkt die reeds betrekking hebben op het RBA-niveau.

De INRO/TNO-schoolverlatersinformatie kan ook gebruikt worden voor het in beeld brengen van de relatieve werkloosheid op RBA-niveau van schoolverlaters naar opleidingstype, zoals dus onlangs door het ROA is gedaan (zie paragraaf 4.1.).

De mogelijke betekenis van de in paragraaf 4.1. genoemde initiatieven, die zijn gericht op het vergroten van de toegankelijkheid van de bestaande informatie, voor het I-See! informatiesysteem is minder gemakkelijk aan te geven. Zoals in schema 2.1. reeds werd aangegeven, fungeren werkloosheidscijfers en vacaturecijfers slechts als achtergrondgegevens voor de studie- en beroepskeuzevoorlichting. Prognoses op basis van trendextrapolaties van deze gegevens, zoals voorgesteld in de Methodiek scholingsplanning, zijn vanuit dat oogpunt minder wenselijk en leveren zelfs het gevaar op van het ontstaan van varkenscycli op de arbeidsmarkt, door de uitvergroting van de actuele situatie die optreedt bij het extrapoleren van recente ontwikkelingen.

Over de inhoud van de monitor lokale arbeidsmarkt van VNG-SGBO bestaat momenteel nog te 
veel onduidelijkheid om meer in concreto in te gaan op de bijdrage die dit project zou kunnen leveren aan I-See!. Met name de verzamelde informatie over specifieke groepen als allochtonen of gehandicapten zou mogelijk bruikbaar kunnen zijn.

Het gezamenlijke onderzoekprogramma onderwijs-arbeid Zuid-Holland heeft als belangrijk nadeel dat het slechts betrekking heeft op een enkele provincie. Bovendien zal een niet-gecoördineerde 'bottom-up' aanpak vanuit de regio's zelf, tot onoverkomenlijke afstemmingsproblemen leiden bij gebruik in een informatiesysteem als I-See!. 


\section{BESLUIT}

Zoals in het inleidende hoofdstuk reeds werd opgemerkt is dit inventariserende 'state of the art' rapport samengesteld met de bedoeling een bijdrage te leveren aan de verbetering van de informatievoorziening met betrekking tot de regionale arbeidsmarkt.

In het tweede hoofdstuk werd een schets gegeven van het grote belang van regionale arbeidsmarktinformatie voor uiteenlopende gebruikersgroepen. Daarbij werd geconstateerd dat voor alle vier beschreven directe gebruiksdoelen - de studie- en beroepskeuzevoorlichting, het arbeidsvoorzieningsbeleid, de onderwijs- en curriculumplanning en het wervings- en personeelsbeleid van arbeidsorganisaties - er een duidelijke behoefte bestaat aan in vergaande mate naar opleiding en/of beroep gedesaggregeerde arbeidsmarktinformatie.

Daarnaast is regionale arbeidsmarktinformatie van belang voor wat in dit rapport werd bestempeld als de indirecte gebruiksdoelen: verkeers- en vervoersbeleid, woningbouwbeleid e.d.. Voor deze gebruiksdoelen is het vereiste desaggregatieniveau naar sector, beroep en opleiding echter veel geringer. Wel is er vanuit deze gebruiksdoelen een expliciete behoefte aan arbeidsmarktprognoses.

Het derde hoofdstuk geeft een beeld van de ontoereikendheid van de op dit moment beschikbare regionale arbeidsmarktinformatie. Met name verbijzonderingen van de werkzame bevolking, de vacatures en het aanbod van schoolverlaters, naar opleiding en beroep zijn vrijwel niet mogelijk op basis van het voorhanden zijnde statistische materiaal.

In het vierde hoofdstuk wordt een negental recentelijk genomen initiatieven beschreven, die als doel hebben het aanbod van regionale arbeidsmarktinformatie te verbeteren. De initiatieven zijn daarbij ingedeeld in een drietal categorieën gericht op respectievelijk het:

- herordenen en toegankelijk maken van reeds bestaande informatie;

- ontwikkelen van nieuwe meetinstrumenten;

- genereren van informatie op basis van (prognose)modellen.

De drie genoemde initiatieven die primair gericht zijn op het herordenen en toegankelijk maken van reeds bestaande informatie, kunnen vooral een nuttige rol spelen bij de vertaalslag van de bestaande informatie naar de diverse gebruikersgroepen. Daarbij zal men naar alle waarschijnlijkheid momenteel met allerlei beperkingen worden geconfronteerd, die slechts kunnen worden opgelost met behulp van de arbeidsmarktinformatie die verkregen zou kunnen worden door het ontwikkelen van nieuwe meetinstrumenten en het opstellen van 
arbeidsmarktprognoses.

De Methodiek scholingsplanning van het Centraal Bureau van de Arbeidsvoorzieningsorganisatie is momenteel het meest uitgewerkte initiatief, gericht op het inzichtelijk maken van de regionale arbeidsmarkt met behulp van het beschikbare datamateriaal. De voorgestelde methodiek is echter in sterke mate gericht op een specifieke gebruikersbehoefte (de scholingsplanning) binnen de arbeidsvoorzieningsorganisatie.

De voorgestelde 'monitor lokale arbeidsmarkt' van VNG-SGBO zou met name een nuttige rol kunnen spelen bij het toegankelijk maken van de gegevens over het zoek- en wervingsgedrag, de specifieke doelgroepen van het arbeidsmarktbeleid en van allerhande kwalitatieve beleidsinformatie. Met name ten aanzien van deze aspecten is dit initiatief complementair aan de andere initiatieven. Het VNG-SGBO initiatief is zeer ambitieus ten aanzien van de te maken vertaalslag naar de beleidsmakers, door ook een handleiding op te willen stellen van de beleidsinitiatieven die in een bepaalde (arbeidsmarkt)situatie relevant zijn, om op basis daarvan tot besluitvorming te komen.

Het gezamenlijke onderzoekprogramma onderwijs-arbeid Zuid-Holland heeft als belangrijk voordeel dat binnen een bepaalde regio de diverse belangstellenden commitment verkrijgen met de opbouw van het informatiesysteem. Een mogelijk nadeel van een dergelijke regio-specifieke aanpak is dat de onderlinge vergelijkbaarheid van de arbeidsmarktinformatie tussen de verschillende regio's verloren gaat. Alleen een stringente coördinatie kan dit probleem voorkomen.

In het algemeen kan worden gesteld dat de drie initiatieven, hoewel in meer of mindere mate gericht op verschillende doelgroepen, elkaar voor een niet onbelangrijk deel in hun taakstelling overlappen. Samenwerking, al dan niet op basis van een onderlinge taakafbakening, tussen de diverse initiatieven zou duidelijk vruchten kunnen afwerpen. Gezien de slechts zeer beperkte mate waarin tot nu toe concreet invulling aan deze initiatieven is gegeven en de omvangrijke ontwikkelingskosten van het ontwikkelen van adequate beleidsgerichte gebruiksvriendelijke informatiesystemen, lijkt het een juist moment om te komen tot een onderlinge afstemming van de te ondernemen onderzoekactiviteiten. Bovendien is er een duidelijk raakvlak met het door het LDC ontwikkelde informatiesysteem I-See!, dat een belangrijke voorbeeldfunctie zou kunnen vervullen voor op andere doelgroepen gerichte informatiesystemen c.q. 'vertaalslag'-projecten.

Van de drie initiatieven die (primair) gericht zijn op het ontwikkelen van nieuwe meetinstrumenten vullen de RUBS-schoolverlatersenquête en het GMD-functie-informatiesysteem twee duidelijk afgebakende, complementaire lacunes op in de momenteel beschikbare 
regionale arbeidsmarktinformatie. Beide initiatieven voldoen, in tegenstelling tot het overgrote deel van de ad hoc schoolverlaters- en/of arbeidsmarktonderzoeken, in principe ook aan de volgende cruciale vereisten voor een bruikbaar meetinstrument (zie ook Van Dam, De Grip en Heijke, 1990):

- representativiteit van de informatie;

- koppelbaar aan bestaande databestanden: - eenduidig koppelbare classificaties naar sector, beroep en opleiding;

- intern en extern consistente definities;

- periodieke herhaling;

- actualiteit;

- toegankelijkheid.

Het modulaire informatie-instrument van NIPO, EIM en BvEA is van een geheel andere aard dan de beide bovengenoemde initiatieven. Het instrument bestrijkt de volle breedte van de arbeidsmarkt en heeft daarmee in principe raakvlakken met alle andere genoemde initiatieven. Op basis van de steekproefomvang en de voorgestelde metingsmethode mag niet worden verwacht dat met dit informatie-instrument over de volle breedte van de arbeidsmarkt kwantitatieve arbeidsmarktinformatie op een laag aggregatieniveau naar sector, beroep en opleiding zal worden verkregen, die verder rijkt dan de momenteel reeds beschikbare informatie uit de ERBO-, EBB- en CBS-vacature-enquête. De betekenis van het instrument is vooral hierin gelegen dat vanuit een breder kader een kwalitatieve analyse van de arbeidsmarktproblematiek in een bepaalde regio, of een kwantitatief beeld van een bepaald arbeidsmarktsegment in een regio kan worden gegeven. In het laatste geval zal dan van te voren eerst globaal moeten worden vastgelegd welke probleemcategorieën op de arbeidsmarkt nader in beeld moeten worden gebracht.

De drie initiatieven die zijn getypeerd als het bouwen van prognosemodellen hebben, zoals in het vorige hoofdstuk reeds werd opgemerkt, een sterk complementair karakter. De prognoses van Arbeidsvoorziening (OAV) richten zich met name op het prognosticeren van de sectorale werkgelegenheidsontwikkeling; de INRO/TNO prognoses hebben betrekking op de uitstroom uit het voltijds dagonderwijs. Dit lijkt veel op de uitgangssituatie van het ROA bij het opstellen van de landelijke arbeidsmarktprognoses naar beroep en opleiding. Het ROA maakt daarbij gebruik van enerzijds de sectorale werkgelegenheidsprognoses van het Centraal Planbureau en anderzijds de SKILL, WORSA en RHOBOS schoolverlatersprognoses van het Ministerie van Onderwijs en Wetenschappen. Omdat de expertise van het ROA bij uitstek betrekking heeft op de modellering van de beroepenstructuur van bedrijfssectoren, de opleidingenstructuur van beroepen en de mede op basis daarvan te genereren arbeidsmarktindicatoren naar opleiding en 
beroep, ligt het voor de hand deze expertise bij het genereren van regionale arbeidsmarktinformatie op soortgelijke wijze te benutten als op het landelijke niveau. Dit maakt het wel noodzakelijk dat een versterkte samenwerking tot stand komt, op basis van een duidelijke onderlinge afbakening van activiteiten tussen OAV, INRO/TNO en ROA. Daar zowel de sectorale werkgelegenheidsprognoses als de prognoses van het aanbod van schoolverlaters een cruciale input vormen voor de ROA-berekeningen, is het van groot belang dat ook de timing en frequentie waarmee de prognoses worden opgesteld op elkaar worden afgestemd. Tevens zullen afspraken gemaakt moeten worden ten aanzien van de kwaliteitsbewaking.

Tot nu toe is uitsluitend ingegaan op de onderlinge vergelijkbaarheid en de wens tot samenwerking tussen de initiatieven die elk tot dezelfde categorie worden gerekend. Het ligt voor de hand dat ook de samenwerking tussen de verschillende soorten initiatieven meer dan gewenst is. Zo zullen zowel de RUBS- als de GMD-gegevens, naast de waarde die ze op zichzelf reeds hebben, ook een belangrijke bijdrage kunnen leveren aan de mogelijkheden om te komen tot betere arbeidsmarktprognoses. Dergelijke meetinstrumenten zullen het eveneens mogelijk maken de initiatieven gericht op het toegankelijk maken van de beschikbare arbeidsmarktinformatie in belangrijke mate te verrijken.

De arbeidsmarktinformatie die wordt gegenereerd met behulp van de prognosemodellen zal de beleidsgerichte informatie-instrumenten die gebruik maken van de beschikbare arbeidsmarktinformatie meer inhoud kunnen geven. Naast de bij de eerste categorie initiatieven genoemde informatie-instrumenten, geldt dit vanzelfsprekend ook voor de door het LDC te ontwikkelen regionale informatieprodukten, zoals het te regionaliseren informatiesysteem I-See!. Ook een onderlinge afstemming en samenwerking tussen enerzijds de modelbouw ten behoeve van regionale arbeidsmarktprognoses en anderzijds de modelbouw ten behoeve van de indirecte gebruikersbehoeften vanuit de Rijksplanologische Dienst e.d. is wenselijk.

Het zou niet terecht zijn bij het hier gehouden pleidooi voor samenwerking voorbij te gaan aan de huidige belangrijke rol die het CBS speelt bij het genereren van landelijke en regionale arbeidsmarktinformatie. Het zou een goede zaak zijn deze rol verder uit te bouwen. Zo zou het CBS een meer aktieve rol kunnen spelen bij het vergroten van de arbeidsmarktrelevantie van de huidige beroepen- en opleidingenclassificaties, hetgeen de kwaliteit van de verzamelde informatie duidelijk ten goede zou kunnen komen. Ook kan men zich afvragen of het CBS in staat gesteld zou moeten worden de schaal van een belangrijk meetinstrument als de Enquête Beroepsbevolking in aanzienlijke mate te vergroten, waardoor het mogelijk wordt ook op regionaal niveau meer gedetailleerde informatie naar beroep en opleiding te verstrekken. Daarbij zou bijvoorbeeld kunnen worden gedacht aan een aanvullende beknopte telefonische enquête. 


\section{LITERATUUR}

Arbeidsvoorziening (1990-I), Regionaal statistische arbeidsmarkt dokumentatie, deel 1 en 2, OAV-Rapporten 90-07 en 90-21, Rijswijk.

Arbeidsvoorziening (1990-II), Regionale Arbeidsmarkt Prognose 1990-1995, OAV-Rapport 9019, Rijswijk.

Beekman, Th.B.J., A. de Grip (1991), Werkloosheidsindicatoren voor schoolverlaters, ROA-RM1991/1, Maastricht.

Dam, J.W. van, A. de Grip, J.A.M. Heijke (1990), Huidig follow-up onderzoek levert dikwijls beperkte resultaten, in: $U \& H$, jrg. 36, nr. 4, pp. 260-266.

Grip, A. de, R.K.W. van der Velden, M.H. Wieling (1991), Indicatoren aans/uiting onderwijsarbeidsmarkt MDGO, ROA-R-1991/2, Maastricht.

Huson, J.M., M.J. Meesters (1989), Wegwijzer arbeidsmarktinformatie voor de provincie ZuidHolland, Research voor Beleid, Leiden.

Mul, C.A.M., J.H.F. Meijer, P. van Ham (1990), Methodiek Scholingsplanning, Arbeidsvoorzieningsorganisatie centraal bureau, Rijswijk.

Pere, H.M. (1986), Arbeidsmarktvoorlichting: een voorstel voor interdisciplinaire opbouw, Centrum voor Beleidsanalyse en Advies, Nijmegen.

Vermeulen, M. (1990), Regionalisering uitstroom voortgezet onderwijs (RUVO), INRO/TNO, Delft. 